\title{
Rediscovery of Bertrand's Sorbose Bacterium (Acetobacter aceti subsp. xylinum): Proposal to Designate NCIB 11664 in Place of NCIB 4112 (ATCC 23767) as the Type Strain of Acetobacter aceti subsp. xylinum
}

\author{
Request for an Opinion \\ M. GILLIS,${ }^{1}$ K. KERSTERS, ${ }^{1}$ F. GOSSELÉ, ${ }^{1}$ J. SWINGS, ${ }^{1}$ J. DE LEY, ${ }^{1 *}$ A. R. MACKENZIE, ${ }^{2}$ AND I. J. \\ Laboratorium voor Microbiologie en microbiële Genetica, Rijksuniversiteit, B-9000 Gent, Belgium, ${ }^{1}$ and \\ National Collection of Industrial Bacteria, Torry Research Station, Aberdeen AB9 8DG, Scotland ${ }^{2}$
}

\begin{abstract}
None of three culture collection strains (NCIB 4112, ATCC 23767, and CIP 57.14) presumed to be Bertrand's sorbose bacterium (type strain of Acetobacter aceti subsp. xylinum) was found to be a member of the genus Acetobacter. These three strains were identical, displayed considerable phenotypic differences compared with descriptions of the original sorbose bacterium published before 1959, and belonged to Gluconobacter oxydans. However, a 1949 Sordelli-dried culture of strain NCIB 4112 was revived at the National Collection of Industrial Bacteria and was found to belong to the genus Acetobacter. This culture showed similarities to other $A$. aceti subsp. xylinum strains and therefore is most similar to the culture originally deposited in 1933 by Bertrand in the National Collection of Type Cultures. The new accession number of the revived sorbose bacterium is NCIB 11664, and we request an opinion to designate this strain as the type strain of A. aceti subsp. xylinum in place of strain NCIB 4112.
\end{abstract}

In 1896, Bertrand $(1,2)$ isolated and described a bacterium capable of producing sorbose from sorbitol, and consequently he named this bacterium "la bactérie du sorbose." Because of its morphological, cultural, and biochemical properties, this sorbose bacterium was identified as "Acetobacter xylinum" (Brown 1886) Holland $1920(3,4,6)$. The most distinctive characteristics of this organism are overoxidation of acetic acid, a strong ketogenic activity from mannitol, sorbitol, and glycerol, and formation of a thick leathery pellicle (3). The importance of this strain is that it led to the discovery of ketogenesis (3) and later to the Bertrand-Hudson rule (8). This strain was deposited by G. Bertrand in the National Collection of Type Cultures, London, England, in 1933 as strain NCTC 4112 and came from there to the National Collection of Industrial Bacteria (NCIB), Aberdeen, Scotland, in 1949 (NCIB 4112). The typical properties of this organism were confirmed by Tošić in 1942 (personal communication) and by Kulka and coworkers $(9,10)$, who drew attention to phenotypic similarities between strain NCIB 4112 and "A. xylinum" NCIB 5346. In Bergey's Manual of Determinative Bacteriology, 8th ed. (5), "Acetobacter xylinum" was renamed Acetobac- ter aceti subsp. xylinum, and according to the Approved Lists of Bacterial Names (12) strain NCIB 4112 is the type strain of this subspecies. The NCIB supplied strain NCIB 4112 in 1957 to the Collection of the Institut Pasteur, Paris, France and in 1968 to the American Type Culture Collection Rockville, Md. (designations, CIP 57.14 and ATCC 23767, respectively).

We prepared protein electropherograms of strains NCIB 4112, ATCC 23767, and CIP 57.14 by using previously described techniques (13) and found that these electropherograms were identical, as expected (Fig. 1). However, deoxyribonucleic acid-ribosomal ribonucleic acid (rRNA) hybridizations and phenotypical analyses indicated that in contrast to other $A$. aceti subsp. xylinum strains, these strains do not belong in the genus Acetobacter, but are definitely members of Gluconobacter oxydans (7). For example, strain NCIB 4112 does not overoxidize acetic acid, does not form a leathery pellicle, and shows no ketogenic activity or very weak ketogenic activity on mannitol, sorbitol, and glycerol. The vigorous oxidation of these polyols to ketoses by the authentic sorbose bacterium (3) was in fact the origin of the discovery of ketogenesis. Figure 1 shows that 


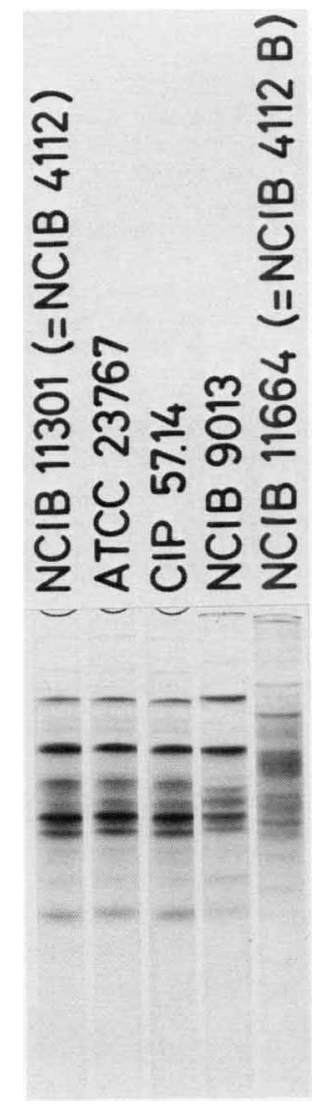

FIG. 1. Protein electropherograms of "Acetobacter aceti subsp. xylinum" strains NCIB 4112 (= NCIB 11301), ATCC 23767, and CIP 57.14, G. oxydans NCIB $9013^{\mathrm{T}}$ and revived Bertrand's sorbose bacterium $($ A. aceti subsp. xylinum) strain NCIB 4112B (= NCIB 11664).

the protein pattern of $G$. oxydans subsp. oxydans NCIB $9013^{\mathrm{T}}$ (= ATCC $19357^{\mathrm{T}}$ [type strain of $G$. oxydans]) is very similar to the patterns on the electropherograms of NCIB 4112 and its descendants. Thus, strain NCIB 4112 does not now correspond to the original sorbose bacterium, which must have been interchanged with a strain of $G$. oxydans between 1933 and 1957. Comparisons with the protein electropherograms of about 100 Gluconobacter strains (Kersters, unpublished data) suggest that the culture of the authentic sorbose bacterium may have been interchanged inadvertently with a culture of NCIB 3734, NCIB 4943, NCIB 6426, or NCIB 8131; all of these strains have almost identical protein profiles.

As a consequence of these results, workers at the NCIB revived a Sordelli-dried (surface growth mixed with horse serum in a cottonplugged inner tube, with phosphorus pentaoxide in an outer tube that is sealed under a vacuum) culture of the sorbose bacterium prepared in 1949 either at the National Collection of Type Cultures or at the NCIB. This subculture, which we designated NCIB 4112B, was found to be pure and to be capable of producing a thick pellicle. This strain was examined by the methods $(7,13)$ used for strain NCIB 4112 .

With ${ }^{14} \mathrm{C}$-labeled rRNA from $G$. oxydans subsp. oxydans NCIB $9013^{\mathrm{T}}$, strain NCIB 4112B forms a deoxyribonucleic acid-rRNA hybrid with a thermal denaturation temperature of $76.3^{\circ} \mathrm{C}$ and an rRNA binding percentage of $0.20 \%$, proving that strain NCIB 4112B belongs definitely in Acetobacter (thermal denaturation temperature, 74.5 to $78.3^{\circ} \mathrm{C}$; rRNA binding, 0.10 to $0.28 \%$ [7]). The protein pattern of NCIB 4112B (Fig. 1) is completely different from that of strain NCIB 4112 and differs also from the patterns of approximately 100 Gluconobacter strains.

Phenotypically, strain NCIB 4112B corresponds to the original description of the bacterie du sorbose. It does overoxidize acetic acid and lactate, it does form a thick leathery pellicle, and it does effect strong ketogenesis from mannitol, sorbitol, and glycerol. In colony morphology and in cultural aspects this strain is very similar to other A. aceti subsp. xylinum strains, such as strains NCIB 613 and NCIB 5346 (Gosselé and Swings, unpublished data). It should be noted that the A. aceti subsp. xylinum strains do not form a phenotypically and electrophoretically homogeneous group of bacteria (F. Gosselé and P. Pauwels, unpublished data). The results of an extensive phenotypic analysis of Acetobacter will be published elsewhere.

Our conclusion is that strain NCIB 4112B is most probably a descendant of the culture originally deposited by Bertrand in the National Collection of Type Cultures in 1933.

The NCIB has decided to keep both strains and to use the following designations: (i) NCIB 11301 (= NCIB 4112), now known to belong to G. oxydans; and (ii) NCIB 11664 (= NCIB 4112B), the authentic Bertrand strain belonging to $A$. aceti subsp. xylinum. According to the Approved Lists of Bacterial Names (12), strain NCIB $4112(=$ ATCC $23767=$ NCIB $11301=$ CIP 57.14) is the type strain of Acetobacter aceti subsp. xylinum; however, we have shown here that this strain should be replaced by NCIB 11664 (= NCIB 4112B) according to Rules $18 \mathrm{~g}$ and $18 \mathrm{i}$ of the International Code of Nomenclature of Bacteria (11).

\section{ACKNOWLEDGMENTS}

J.D.L. is indebted to the Fonds voor Kollektief Fundamenteel Onderzoek for research and personnel grants. 


\section{LITERATURE CITED}

1. Bertrand, G. 1896. Préparation biochimique du sorbose C. R. Acad. Sci. 122:900-903.

2. Bertrand, G. 1898. Recherches sur la production biochimique du sorbose. Ann. Inst. Pasteur (Paris) 12:385-399.

3. Bertrand, G. 1904 . Etude biochimique de la bactérie du sorbose. Ann. Chim. Phys. 3:181-288.

4. Brown, A. J. 1886. On an acetic ferment which forms cellulose. J. Chem. Soc. Trans. 49:432-439.

5. De Ley, J., and J. Frateur. 1974. Genus Acetobacter Beijerinck 1898 , 215, p. 276-278. In R. E. Buchanan and N. E. Gibbons (ed.), Bergey's manual of determinative bacteriology, 8th ed. The Williams \& Wilkins Co., Baltimore.

6. Emmerling, O. 1899. Zur Kenntniss des Sorbosebakteriums. Ber. Dtsch. Chem. Ges. 32:541-542.

7. Gillis, M., and J. De Ley. 1980. Intra- and intergeneric similarities of the ribosomal ribonucleic acid cistrons of Acetobacter and Gluconobacter. Int. J. Syst. Bacteriol. 30: $7-27$
8. Hann, R. M., E. B. Tilden, and C. S. Hudson. 1938. The oxidation of sugar alcohols by Acetobacter suboxydans. J. Am. Chem. Soc. 60:1201-1203.

9. Kulka, D., J. M. Preston, and T. K. Walker. 1949. Giant colonies of Acetobacter species as an aid to identification. J. Inst. Brew. London 55:141-146.

10. Kulka, D., J. Singh, R. M. Nattrass, A. N. Hall, and T. K. Walker. 1958. Studies on vinegar bacteria. J. Sci. Food Agric. 8:487-492.

11. Lapage, S. P., P. H. A. Sneath, E. F. Lessel, V. B. D. Skerman, H. P. R. Seeliger, and W. A. Clark (ed.). 1975. International code of nomenclature of bacteria. 1975 Revision. American Society for Microbiology, Washington, D.C.

12. Skerman, V. B. D., V. McGowan, and P. H. A. Sneath. 1980. Approved lists of bacterial names. Int. J. Syst. Bacteriol. 30:225-420.

13. Swings, J., M. Gillis, K. Kersters, P. De Vos, F. Gosselé, and J. De Ley. 1980. Frateuria, a new genus for "Acetobacter aurantius." Int. J. Syst. Bacteriol. 30:547-556. 